\title{
WORKFORCE SIZING AND SCHEDULING FOR A SERVICE CONTRACTOR USING INTEGER PROGRAMMING
}

\author{
D.G. Conradie and J.W. Joubert \\ Department of Industrial and Systems Engineering \\ University of Pretoria, South Africa \\ johan.joubert@up.ac.za
}

\begin{abstract}
Operations Research is perceived to be on the verge of demise as a decision support tool in industry. However, this is not true, since the relevancy and interdisciplinary nature of Operations Research makes it an indispensable part of operations management. What should rather be asked is how Operations Research is introduced to undergraduate industrial engineering students. This paper reports on one of the optimisation initiatives undertaken for a service contractor using integer programming as part of a semester project. Although the model addresses specific business issues related to the contractor, it can easily be generalised for other applications.
\end{abstract}

\section{OPSOMMING}

Operasionele Navorsing word geag as 'n kwynende besluitnemingsinstrument in die nywerheid. Dit is egter onwaar, aangesien die toepaslikheid en interdissiplinêre karakter van Operasionele Navorsing dit ' $\mathrm{n}$ onmisbare rol laat speel in operasionele bestuur. Die vraag wat eerder gevra moet word is hoe Operasionele Navorsing aan voorgraadse bedryfsingenieurswesestudente aangebied word. Hierdie artikel doen verslag oor een van die optimerings-inisiatiewe wat as deel van ' $n$ semesterprojek vir 'n diensverskaffer uitgevoer is, en maak van heeltal-programmering gebruik. Alhoewel die model kontrakteur-spesifieke besigheidsreëls aanspreek, kan dit maklik veralgemeen word vir wyer toepassing. 


\section{INTRODUCTION}

Operations Research is taught at numerous South African engineering and management faculties at tertiary level, but acceptance of the optimisation techniques are often questioned at shop-floor level in industry. Leinbach and Stansfield [3] address numerous complaints from the operational level with regard to industrial engineering (IE) professionals. Many industrial engineers have lost touch with the action in companies and spend a lot of time on complicated models where the assumptions are so plentiful that it is impossible to challenge the validity of these models over time.

In discussing the denouement of Operations Research, Ackoff [1] identifies three major effects on the practice of Operations Research as a result of academics' obsession with techniques. Firstly, problematic situations are frequently sourced, selected and distorted so as to favour the application of a specific technique. A second effect is the diluted application of techniques as a result in the techniques being introduced to diverse professionals with little background of the fundamentals of operations research. The third, and probably the most detrimental effect is the classification of operations research as an isolated discipline, as opposed to the original interdisciplinary characteristic of Operations Research.

The thrust towards identifying and solving real-life problems using Operations Research is expressed in Joubert and Steyn [2], as their paper reports on a project undertaken for an undergraduate module in Operations Research at third-year level. The emphasis of their endeavour is to enable students to identify an opportunity for improvement where basic modelling techniques can be employed. The opportunity need not require complex solution methods, as the purpose of the project is to foster students confidence with regard to modelling and optimisation initiatives, and to add value to real-life situations in the process. Thie paper reports on the initiative, and the solution, from one of the projects submitted for the third-year Operations Research module in the Department of Industrial and Systems Engineering at the University of Pretoria.

\section{PROBLEM ENVIRONMENT}

The Ground Services function oversees the overall tidiness of the University of Pretoria's campuses, and the responsibility for the main campus grounds is contractually outsourced to a private company. In an attempt to assist the contractor to ensure a favourable outcome when the contract is reviewed at the end of 2004, the authors have embarked on an optimisation exercise.

The outsourced contract requires the contractor to fulfil the complete maintenance function for five distinct areas, namely lawns, flowerbeds, parking areas, pavements, and roads. These tasks are denoted by $i=\{1,2, \ldots, 5\}$. Two half-day (3.5 hour) timeslots are allocated each day, resulting in twelve time periods per week, denoted by $j=\{1,2, \ldots, 12\}$. The year is divided into two working seasons, summer and winter, and is denoted by $m=\{1,2\}$.

The result of the current scenario, however, is inadequate service levels as not all work can be completed on a weekly basis with the current work allocation. Currently 27 workers are employed during the week, and 14 workers on Saturdays, resulting in a weekly wage expenditure of R12,480. Workers are randomly assigned to tasks and areas, and the allocation 
of tasks follows certain general business rules:

- workers should preferably perform at least three tasks per 12-period week,

- no worker may do the same task for more than two consecutive time periods,

- a constant number of workers are required from Mondays to Fridays: time periods 1 through 10. For example, if twenty workers are assigned for weekdays, then the total number of weekday workers must add up to twenty for every week, although the twenty workers may be assigned to different tasks on different days in different weeks;

- a different number of workers may be employed on Saturdays: time periods 11 and 12 . Weekend workers are treated as contract or piece-workers, and it would be possible to hire them on an ad-hoc basis. Weekend workers may, or may not include weekday workers, as they are treated independently. The allocation of duties may vary, but the number of weekend workers must be constant over the various weeks.

- the total number of workers employed should remain constant for the duration of the contract. This holds true for both the total number of weekday workers, as well as the total number of weekend workers.

Further constraints are

- that all work must be completed, and

- equipment availability limits the number of workers that can be assigned to specific tasks.

Information regarding the area sizes $\left(\mathrm{m}^{2}\right)$, and the 'process times' $\left(\mathrm{min} / \mathrm{m}^{2}\right)$ is obtained and used to determine the number of periods that are required for each task. This calculation is done separately for each season.

\section{WORKFORCE SIZING AND SCHEDULING}

Schrage [6] states that covering problems tend to rise in service industries, as the crucial feature is the set requirements that must be covered. Various activities are available, each of which helps cover some, but not all, the requirements. In this paper the requirements are the number of periods that are required for each ground task to be completed, while the activities refer to the shift patterns or schedules. Although this type of problem is also referred to as Shift Scheduling Problems [4] or Staffing Problems [6], the authors find the term Workforce Sizing and Scheduling to be the most descriptive [7]. The objective is to determine the minimum number of workers required to perform all the necessary work, and to schedule them accordingly. An upper limit of 50 workers is arbitrarily chosen, since the current 41 workers do not yield a feasible solution (all work cannot be completed). The upper limit will only impact on the size of the model (number of variables and constraints). The computational time to find the optimal solution, however, proved insensitive to the upper limit chosen.

\subsection{Current equipment levels}

In modelling the workforce-sizing and scheduling model, the main decision variable, $x_{i j k m}$, determines whether, and when a specific worker is assigned to a job. 


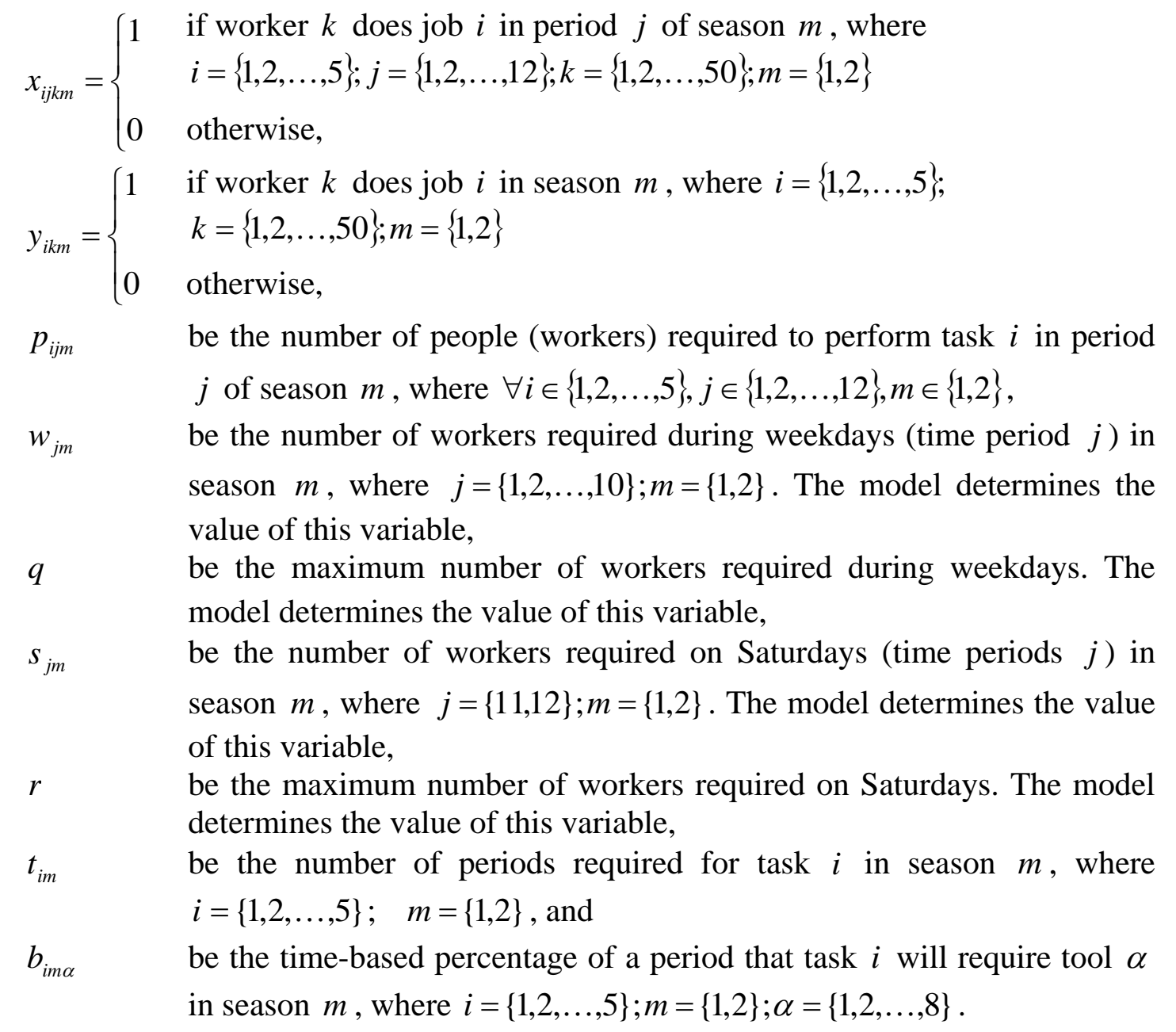

Then

$$
\min z=\left(5 c_{1} q+c_{2} r\right) \beta
$$

subject to

$$
\begin{array}{ll}
\sum_{i=1}^{5} p_{i j m} \leq w_{j m} & \forall j \in\{1,2, \ldots, 10\} ; m \in\{1,2\} \\
w_{j m} \leq q & \forall j \in\{1,2, \ldots, 10\} ; m \in\{1,2\} \\
\sum_{i=1}^{5} p_{i j m} \leq s_{j m} & \forall j \in\{11,12\} ; m \in\{1,2\} \\
s_{j m} \leq r & \forall j \in\{11,12\} ; m \in\{1,2\} \\
\sum_{j=1}^{12} p_{i j m} \geq t_{i m} & \forall i \in\{1,2, \ldots, 5\} ; m \in\{1,2\} \\
\sum_{i=1}^{5} b_{i m \alpha} p_{i j m} \leq n_{\alpha} & \forall j \in\{1,2, \ldots, 12\} ; m \in\{1,2\} ; \alpha \in\{1,2, \ldots, 8\}
\end{array}
$$




$$
\begin{aligned}
& p_{i j m} \leq \beta \sum_{\delta=1}^{10} p_{i \delta m} \quad \forall i \in\{1,2, \ldots, 5\} ; j \in\{1,2, \ldots, 10\} ; m \in\{1,2\} \\
& \beta \leq 1 \\
& \sum_{k=1}^{30} x_{i j k m}=p_{i j m} \\
& \forall i \in\{1,2, \ldots, 5\}, j \in\{1,2, \ldots, 12\}, m \in\{1,2\} \\
& \sum_{h=1}^{3} x_{i, h+j-1, k, m} \leq 2 \\
& \forall i \in\{1,2, \ldots, 5\}, j \in\{1,2, \ldots, 10\}, \\
& k \in\{1,2, \ldots, 50\}, m \in\{1,2\} \\
& \sum_{i=1}^{5} x_{i j k m} \leq 1 \\
& \forall j \in\{1,2, \ldots, 12\}, k \in\{1,2, \ldots, 50\}, m \in\{1,2\} \\
& \sum_{j=1}^{12} x_{i j k m} \leq M \times y_{i k m} \\
& \forall i \in\{1,2, \ldots, 5\}, k \in\{1,2, \ldots, 50\}, m \in\{1,2\} \\
& \sum_{i=1}^{5} y_{i k m} \geq 3 \\
& \forall k \in\{1,2, \ldots, 50\}, m \in\{1,2\} \\
& \beta, b_{\text {im } \alpha} \geq 0 \\
& \forall i \in\{1,2, \ldots, 5\} ; m \in\{1,2\} ; \alpha \in\{1,2, \ldots, 8\} \\
& p_{i j m}, t_{i m}, w_{j m}, s_{j m}, q, r, n_{\alpha} \geq 0 \quad \text { and integer } \\
& \forall i \in\{1,2, \ldots, 5\} ; j \in\{1,2, \ldots, 12\} ; m \in\{1,2\} ; \\
& \alpha \in\{1,2, \ldots, 8\} \\
& x_{i j k m}, y_{i k m} \in\{0,1\} \\
& \forall i \in\{1,2, \ldots, 5\}, j \in\{1,2, \ldots, 12\} \text {, } \\
& k \in\{1,2, \ldots, 50\}, m \in\{1,2\}
\end{aligned}
$$

The objective function indicated in (1) minimizes the total number of workers employed, where $c_{1}$ and $c_{2}$ denote the daily wage for a worker on weekdays, and on a Saturday respectively. The balancing factor $\beta$ attempts to level the workload during weekdays (the first 10 periods of the work-week). Constraints (2) through (5) serve to calculate the total number of workers employed during the week and on Saturdays, based on the model's assignment of workers over the two seasons. The minimum time allocation per task is enforced by (6). Limited tools are addressed in (7) since it influences the number of workers assigned to a task requiring limited resources. The introduction of a balancing factor, $\beta$, in (8) and (9), attempts to level the workload. The matching of workers and task requirements are addressed in (10). Repetition of tasks is limited by (11), while (12) ensures that each worker is only assigned one task during a given period.

Job rotation is the process of shifting workers from one task to another, in an attempt to alleviate "over-routinisation". Robbins [5] indicates that the strengths of job rotation are that it reduces boredom and increases motivation through diversifying the worker's activities. The model attempts to assign workers to tasks in a multi-skilled fashion in (13) and (14). The value $M$ represents a sufficiently large number such that $M \geq \sum_{j=1}^{12} x_{i j k m} . \quad$ In the model a value
of $M=10^{4}$ is used.

The solution of the proposed model indicates a workforce of 28 workers working from periods 1 through 10, and an additional 11 workers working periods 11 and 12. The optimal 
labour cost for the solution is R12,520 - a feasible (all work completed) solution exceeding the current scenario by $0,3 \%$.

The authors challenges the perfectly balanced schedule by removing (8) and (9), and adapting the objective function to

$$
\min z=5 c_{1} q+c_{2} r
$$

and the variable definition constraint (15) to

$$
b_{i m \alpha} \geq 0 \quad \forall i \in\{1,2, \ldots, 5\} ; m \in\{1,2\} ; \alpha \in\{1,2, \ldots, 8\}
$$

The improved solution has 30 workers working periods 1 through 10 , and no additional workers required for the weekend. The optimal objective function value is R12,000 - a feasible solution saving 3,8\% on the current scenario.

\subsection{Equipment recommendations}

Sensitivity analysis indicates substantial slack on the equipment resources. A similar solution (with the same optimal objective function value) can be achieved by reducing the number of tools available of type $\alpha, n_{\alpha}$. The reduction in the number of tools results in a once-off capital saving of approximately R2,700, while the running cost, such as repair and preventative maintenance, have not been taken into account to determine future savings.

The tool set, denoted by $N=\left\{n_{1}, n_{2}, \ldots, n_{8}\right\}$, represents the set of elements, each representing the number of tools available of a specific type. In the execution of the original model the equipment set used is $N=\{7,5,10,15,15,4,4,3\}$. The recommended tool set is $N=\{7,3,3,8,14,1,2,2\}$, and results in the same solution and objective function value.

\section{DISCUSSION}

The model was coded using the LINGO optimisation software [6] that uses a branch-andbound solution algorithm. The small-sized model has 6690 variables of which nearly all are integers, and 7171 constraints. The model is solved in less than seven seconds (5505 iterations) on a standard personal computer with a Pentium IV processor. The software preprocesses the integer model with a branch-and-bound-manager by adding cuts to limit the non-integer feasible region of the linear integer model.

Interpreting the model solution and the sensitivity analysis helps address underlying model assumptions. Although the model assumes perfect working conditions, the proposed solution where workers only work during weekdays, opens up "catching up" opportunities for the contractor by using temporary employment over weekends, as and when required. The state of slack variables identifies certain tools as scarce resources only during the peak-season, and emphasizes the importance of preventative maintenance during the off-season. 


\section{CONCLUSION}

The paper reports on the improvements that a fair-sized integer programming optimisation model proposes. Application of the basic concepts and constraints addressed in the paper can be extended to similar services, production scheduling for labour intensive operations where the tasks are replaced by required products; the service areas are replaced by the product demand; and service time is replaced by unit production time. Further applications identified by students include scheduling police reserve patrols on campus, kitchen staff scheduling at university residences, and telephone service schedules for first-year students.

Operations research is as much an art that is developed through experience, as it is a science. Students are encouraged to initiate optimisation initiatives since it urges them to identify and appreciate the wide field of Operations Research applications. The consequential continuous self-evaluation further fosters critical and reflective practice. This answers the relevancy question of Operations Research at both tertiary education and industry levels: management does require quantitative decision support that could lead to impressive yields, while students embark on a continuous learning experience that involves problem identification, appreciation and solution.

\section{REFERENCES}

[1] Ackoff, R.L. 1999. Ackoff's Best: his Classic Writings on Management, Hoboken: John Wiley and Sons Inc.

[2] Joubert, J.W. and Steyn, D. 2003. 'Operationalising Operations Research', World Transactions on Engineering and Technology Education, 2(1), pp 91-94.

[3] Leinbach, P.A. and Stansfield, T. 2002. 'Living up to expectations', IE Solutions, 34, 11, pp 24-30.

[4] Rardin, R.L. 1998. Optimization in Operations Research, Prentice-Hall, Upper-Saddle River, New Jersey.

[5] Robbins, A.P. 1996. Organizational Behaviour, $7^{\text {th }}$ Edition, Prentice-Hall, UpperSaddle River, New Jersey.

[6] Schrage, L. 2002. Optimization Modeling with LINGO, $5^{\text {th }}$ Edition, LINDO Systems Inc, Chicago, Illinois.

[7] Winston, W.L. 2004. Operations Research: Applications and Algorithms, $4^{\text {th }}$ Edition, Brooks/Cole - Thomson Learning, Belmont. 
